\title{
Redaksioneel
}

\section{Navorsingsuitsette van universiteite - riglyne en beoordeling}

Tesame met onderrig vorm navorsing die belangrikste opgaaf van enige universiteit. Die rol wat navorsing in die ontwikkeling en ontginning van die werklike en potensiële natuurlike en menslike hulpbronne van 'n land speel, kan nie oorbeklemtoon word nie.

Navorsing word binne die subsidieformule vir lopende uitgawes van Suid-Afrikaanse universiteite op twee wyses gesubsidieer. Eerstens ontvang elke universiteit deur middel van die formule 'n bedrag vir die voorsiening van navorsingspersoneel, navorsingsvoorrade en dienste, vir die vervanging en vernuwing van geboueruimtes vir navorsingsaktiwiteite en die aankoop van nuwe boeke en toerusting vir navorsing. Dié bedrag wat dus die basiese onderbou en uitbreiding van navorsingsaktiwiteite aan 'n universiteit voorsien, is nie afhanklik van enige navorsingsuitset nie, maar word slegs bepaal deur studentegetalle en toenames in studentegetalle. Ten einde egter navorsing op die hoogste vlak te stimuleer en daardeur die ontwikkeling van voortreflike navorsingsentra aan universiteite aan te moedig, word die voortreflikste navorsingsuitsette aan universiteite addisioneel tot voorgenoemde "blinde komponent" binne die formule gesubsidieer. As uitgangspunt in hierdie subsidiëring is besluit om een navorsingseenheid toe te ken vir elke oorspronklike navorsingsartikel wat in 'n hoëgehaltenavorsingstydskrif verskyn. Volgens die subsidieformule is die subsidie wat so 'n artikel tans vir 'n universiteit genereer, ongeveer R10 000. Aangesien alle voortreflike navorsing nie noodwendig in navorsingstydskrifte verskyn nie, is twee verdere navorsingsaanwysers, naamlik boeke vir die vakspesialis en patente, daargestel. Navorsingseenhede word dan relatief tot dié van navorsingsartikels aan sodanige navorsingsuitsette toegeken.

Die beleid ten opsigte van die subsidiëring van navorsingsuitsette van universiteite word volledig uiteengesit in die verslag NASOP/NATED 02-014(90/07). Die wyse waarop die navorsingsuitsette van universiteite deur 'n ad hoc-komitee van die Adviesraad vir Universiteite en Technikons (AUT) geëvalueer word, word ook in die verslag uiteengesit. Die verslag bevat verder ook die administratiewe reëlings by die indiening van die navorsingsmateriaal deur universiteite se navorsingskantore en gee ook belangrike riglyne vir die interne evaluering van navorsingsuitsette deur die navorsingskomitees van universiteite voordat dit ingedien word.

Ter inligting word slegs enkele belangrike beleidsriglyne waaroor dikwels onduidelikhede bestaan, hier gegee:

- Ten einde te voorkom dat die genoemde komitee duisende navorsingsartikels wat in navorsingstydskrifte verskyn het, jaarliks moet beoordeel, is besluit om 'n lys van hoëgehaltenavorsingstydskrifte daar te stel en dan alle navorsingsartikels wat daarin verskyn, sonder meer te tel. Sodanige lys is in 1986 saamgestel uitgaande van die volgende sitasie-indekse van die "Institute for Scientific Information":

Science Citation Index

\section{Social Sciences Citation Index}

Arts and Humanities Index.

Sedert 1986 is die lys jaarliks met verdere hoëgehaltenavorsingstydskrifte wat deur universiteite genomineer is en deur die evalueringskomitee goedgekeur is, aangevul. Tans bevat dié lys 6719 tydskrifte. Alleen bona fide-navorsingsartikels in goedgekeurde navorsingstydskrifte kwalifiseer vir subsidie. Dit sluit dus boekbesprekings, vakkundige mededelings, kommentaar wat op uitnodiging op navorsingsartikels gelewer word en vroeë navorsingsopsommings wat later deur 'n volledige artikel opgevolg gaan word, uit.

- Oorspronklike en streng gekeurde navorsingsmateriaal van hoë gehalte in boekvorm word ook tot die navorsingsuitset van universiteite gereken. Proefskrifte, handboeke en studiehandleidings vir voorgraadse studente, intreeredes, verslae oor kontraknavorsing en blote dokumentasie van gevallestudies kwalifiseer egter normaalweg nie. Konferensie/kongresverrigtinge wat nie as 'n lopende volume van 'n bepaalde navorsingstydskrif verskyn nie, maar 'n geleentheidspublikasie is, kan ook in die kategorie "boeke vir die vakspesialis" deur universiteite ingedien word. Elke bydrae word volgens meriete oorweeg en soos 'n artikel in 'n goedgekeurde navorsingstydskrif getel.

- Slegs navorsingsuitsette in die vorm van patente waarvan die finale registrasie by wyse van 'n seëlbrief gesertifiseer kan word, word deur die evalueringskomitee oorweeg.

Die navorsingsuitsette van Suid-Afrikaanse universiteite is reeds ten opsigte van ses akademiese jare geëvalueer en die totale getal navorsingseenhede (in tydskrifartikelekwivalente) wat daaraan toegeken is, word in bygaande figuur getoon.

Die figuur toon 'n aanvanklike vinnige styging en daarna 'n afplatting. Die styging in die navorsingseenhede gedurende 1984 tot en met 1987 is ongetwyfeld hoofsaaklik te wyte aan die stimulus veroorsaak deur die Staat se insentief om uitnemende navorsing by wyse van addisionele subsidie te beloon. Die getal onderrig-/navorsingspersoneel aan Suid-Afrikaanse universiteite het in die tydperk 1984 tot 1989 met ongeveer $15 \%$ toegeneem en het ook deels bygedra tot die vergroting van die navorsingsuitsette. Die gemiddelde getal navorsingseenhede per onderrig-/navorsingspersoneellid was in 1988 vir alle Suid-Afrikaanse universiteite gesamentlik 0,55. Anders gestel: een navorsingseenheid elke 22 maande per onderrig-/navorsingspersoneellid.

Groot verskille bestaan in die navorsingsprestasies van die Suid-Afrikaanse universiteite. Ou, gevestigde universiteite met navorsingstradisies en -infrastrukture van etlike dekades lewer tans gemiddeld tot 1,08 navorsingseenhede per onderrig-/navorsingspersoneellid per jaar. Aan die ander kant van die spektrum is daar egter ook universiteite wat hulle aandag feitlik ten volle toespits op onderrig en feitlik geen navorsing van hoogstaande gehalte lewer nie. 


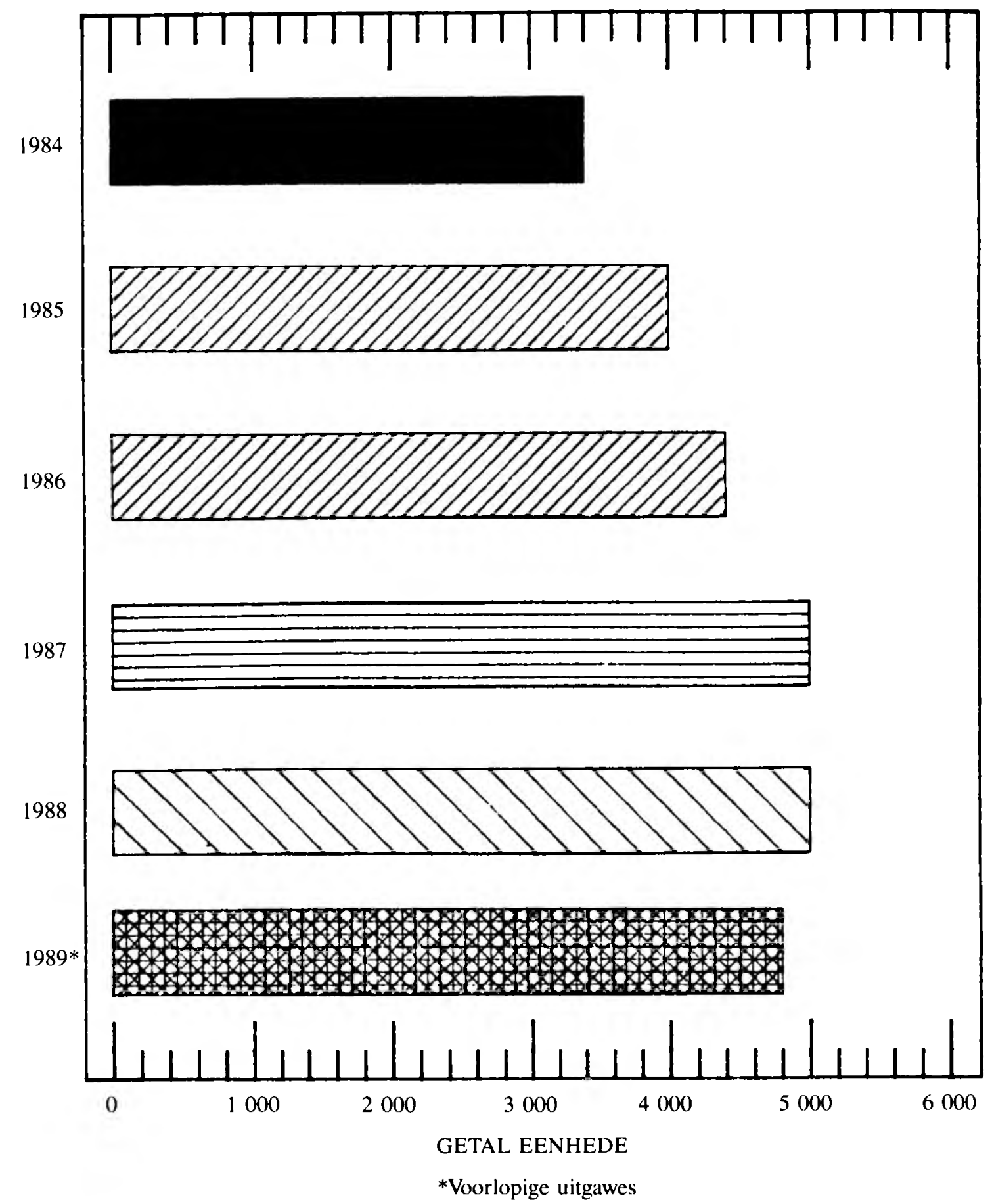

FIGUUR 1: Navorsingsuitsette van universiteite 1984-1989.

Bygaande tabel toon die verdeling van universiteite volgens die gemiddelde getal navorsingseenhede per onderrig-/ navorsingspersoneellid ten opsigte van 1988.

\section{TABEL 1}

Verdeling van universiteite volgens die gemiddelde getal navorsingseenhede per onderrig-/navorsingspersoneellid vir 1988

\begin{tabular}{|l|c|}
\hline $\begin{array}{l}\text { Gemiddelde getal navorsingseenhede } \\
\text { per onderrig-/navorsingspersoneellid }\end{array}$ & Aantal universiteite \\
\hline $0-0,24$ & 7 \\
$0.25-0,49$ & 5 \\
$0.50-0,74$ & 4 \\
$0,75-0,99$ & 1 \\
1,00 en hoër & 1 \\
\hline & 18 \\
\hline
\end{tabular}

Die beleid van die Staat om navorsing van hoë gehalte addisioneel te beloon, het die navorsingsfunksie van elke universiteit in die RSA opnuut onder die kollig geplaas. Dit het bygedra tot die omskepping van die navorsingspotensiaal wat so ryklik aan universiteite beskikbaar is, tot navorsingsresultate wat nie alleen die internasionale aansien van die universiteitswese in die RSA verhoog het nie, maar wat die Suid-Afrikaanse samelewing ook intellektueel, tegnologies en geestelik op die lang termyn sal verryk.

DEPARTEMENT VAN NASIONALE OPVOEDING 